\title{
-765 G>C POLYMORPHISM OF THE COX-2 GENE AND GASTRIC CANCER RISK IN BRAZILIAN POPULATION
}

\author{
Vanessa Maria de Lima Pazine CAMPANHOLO, Aledson Vitor FELIPE, \\ Jacqueline Miranda de LIMA, Célia Aparecida Marques PIMENTA, \\ Rogéria Maria VENTURA and Nora Manoukian FORONES
}

\begin{abstract}
Context - Genomic alterations play important roles in gastric cancer carcinogenesis. Cyclooxygenases (COX) are important enzymes in the maintenance of mucosal integrity and in pathological processes, mainly in inflammation and cancer. The $-765 \mathrm{G}>\mathrm{C}$ COX-2 polymorphism has been implicated in gastric cancer risk. Objective - To evaluate the COX-2 gene polymorphism as a predictor of gastric cancer risk. Methods - One hundred gastric cancer patients and 150 controls were enrolled from a Brazilian centre. Personal data regarding related risk factors, including alcohol consumption and smoking behavior, were collected via questionnaire. DNA was extracted from peripheral blood and the genotypes were analyzed using PCR-restriction fragment length polymorphism. Results - G/G, G/C and C/C genotypes frequencies was $42.7 \%, 50 \%$ and $7.3 \%$, respectively in controls and $59.0 \%, 34.0 \%$ and $7.0 \%$ in gastric cancer. The frequency of the genotypes differed between the groups $(P=0.033)$. A higher risk of gastric cancer was associated with COX-2 -765G/G genotype $(P=0.048$; OR:1.98, 95\% CI $=1.01-3.90)$. Alcohol consumption and smoking in patients with $-765 \mathrm{G} / \mathrm{G}$ genotype also increased the risk of gastric cancer. Conclusion - The $-765 \mathrm{G} / \mathrm{G}$ genotype and the $-765 \mathrm{G}$ allele had been associated with an increased risk for gastric cancer. The presence of smoking and alcohol consumption increased the risk for gastric cancer in subjects with $-765 \mathrm{G} / \mathrm{G}$ genotype compared with the control group. Polymorphism of COX-2 gene and gastric cancer risk HEADINGS - Polymorphism single nucleotide. Gastric cancer. Cyclooxygenase 2.
\end{abstract}

\section{INTRODUCTION}

Gastric cancer (GC) is the fourth most common cancer and the second most frequent cause of cancerrelated death in the world ${ }^{(14)}$. In Brazil, 21,500 new cases of gastric cancer had been occurred in $2012^{(13)}$. There are geographic differences in the prevalence of GC as a consequence of different genetic characteristics, lifestyle factors such as smoking and alcoholism, dietary aspects including meat intake.

Elevated prostaglandin (PG) levels have been observed in patients with cancer and these substances play an important role in cancer progression and metastasis $^{(20,24)}$ The production of PGs depends on the activation of cyclooxygenase (COX). This enzyme converts arachidonic acid into eicosanoids, including PGs. There are two COX isozymes, COX-1 and COX-2. COX-1 is expressed in almost all normal tissues and is involved in vascular homeostasis and platelet aggregation ${ }^{(7)}$. In contrast, COX-2 is almost undetectable under normal conditions and its production is induced by hormones, cytokines, and growth factors. COX-2 expression is associated with inflammatory cell and cancer tissues $^{(1)}$. COX-2 deregulation has been associated with carcinogenesis, including the inhibition of apoptosis, neoangiogenesis, lymphatic invasion, and metasta$\operatorname{sis}^{(9,16,17,27)}$. Increased expression of COX-2 is observed in altered gastric mucosa ${ }^{(26)}$. Furthermore, studies have demonstrated that nonsteroidal anti-inflammatory drugs reduce the incidence of polyps and colon cancer, probably as a result of reduced production of PGs by interfering with COX activity ${ }^{(8,23)}$.

A complex signal transduction pathway is responsible for the regulation of COX-2 expression. Many nuclear proteins interact with the promoter region of COX-2 and play an important role in gene transcription $^{(28)}$. A single nucleotide polymorphism (SNP) in the COX-2 promoter region is known to alter the transcriptional activity of the gene. This SNP affects the binding with some nuclear proteins, changing the susceptibility to cancer ${ }^{(6,25)}$. 
Although some studies have already been done in gastric cancer COX-2 plymorphism the results are conflicting.

The aim of the present study was to investigate the association of the COX-2 -765G $>$ C polymorphism with lifestyle factors and susceptibility to GC.

\section{METHODS}

A case-control study was conducted. The case group consisted of 100 patients with GC (46\% women) seen at the outpatient clinic of the Division of Clinical Gastroenterology, Federal University of São Paulo. Patients with a confirmed histological diagnosis of non-cardia adenocarcinoma were invited to participate in the study. The control group consisted of 150 healthy subjects ( $48 \%$ women) who attended the blood collection service of the Central Laboratory of the São Paulo Hospital. The patients of the case and control groups were admitted during the same period. There was no significant difference in gender $(P=0.756)$ or age $(P=$ 0.731 ) between the groups.

The study was approved by the Ethics Committee of the Federal University of São Paulo with grant number 0154/09, and all patients signed a free informed consent form.

All subjects answered a questionnaire regarding present or past history of cigarette smoking (non smokers and current smokers or former smokers), and alcohol consumption. Patients who drink more than $5 \mathrm{~g} / \mathrm{ethanol} / \mathrm{day}$ were considered positive for alcohol consumption. Clinical characteristics, as clinical stage and survival were obtained.

Peripheral blood was collected in EDTA for the extraction of genomic DNA using the Invisorb Spin Blood Mini Kit (Invitek, Co., Berlin, Germany). COX-2 polymorphism was genotyped by the polymerase chain reaction (PCR)restriction fragment length polymorphism (RFLP) technique.

Genomic DNA was amplified using the following specific primers: forward: 5'-GCTGTATATCTGCTCTATATGC-3' and reverse: '5-CGCTTCCTTTGTCCATCAG-3'. The PCR mixture contained $40 \mathrm{ng}$ genomic DNA, 1x PCR buffer, 125 $\mu \mathrm{mol}$ dNTPs, $1.5 \mathrm{mmol} / \mathrm{L} \mathrm{MgCl}_{2}, 0.75 \mu \mathrm{mol}$ of each primer, and 0.5 unit Taq DNA Polymerase Platinum ${ }^{\circledR}$ (Invitrogen, Carlsbad, CA, USA) in a final volume of $10 \mu \mathrm{L}$. Amplification was carried out under the following conditions: denaturation at $94^{\circ} \mathrm{C}$ for 1 min, followed by 35 cycles of denaturation at $94^{\circ} \mathrm{C}$ for $30 \mathrm{sec}$, annealing at $59^{\circ} \mathrm{C}$ for $1 \mathrm{~min}$, and final extension at $72^{\circ} \mathrm{C}$ for $1 \mathrm{~min}$. After amplification, the PCR product was digested with $0.1 \mathrm{U}$ of the restriction enzyme Aci 1 (New England Biolabs, Ipswich, MA, USA) at $37^{\circ} \mathrm{C}$ for $30 \mathrm{~min}$ and then at $65^{\circ} \mathrm{C}$ for $20 \mathrm{~min}$. The digestion products were separated on agarose gel stained with ethidium bromide.

Twenty percent of samples from patients and controls including samples of each genotype were re-genotyped by two other researchers and results showed $100 \%$ similarity in both of the conditions. Genome sequencing was used to confirm the PCR and RFLP techniques using random samples of both groups. The PCR product of the COX-2 gene was purified using the BigDye XTerminator Purification Kit (Ap- plied Biosystems, Concord, Ontario, Canada) according to the manufacturer's instructions, and sequenced by ABI Prism 3100 sequencer (Applied Biosystems, Concord, Ontario, Canada). The reverse primer was used for sequencing. The electropherogram was analyzed with the Sequence Scanner v 1.0 program. No discrepancy was found after sequencing randomly selected $10 \%$ samples.

All samples were submitted to genotyping of the amplicons by RFLP method with AciI restriction enzyme. The 306-bp PCR product was amplified from specific primers. Patients carrying the wild-type homozygous G/G genotype presented two bands of 118 and $188 \mathrm{bp}$, patients carrying the heterozygous $\mathrm{C} / \mathrm{G}$ genotype presented three bands of 306 , 188 and $118 \mathrm{bp}$, and patients with the homozygous mutant $\mathrm{C} / \mathrm{C}$ genotype showed one band of $306 \mathrm{bp}$ (Figure 1).

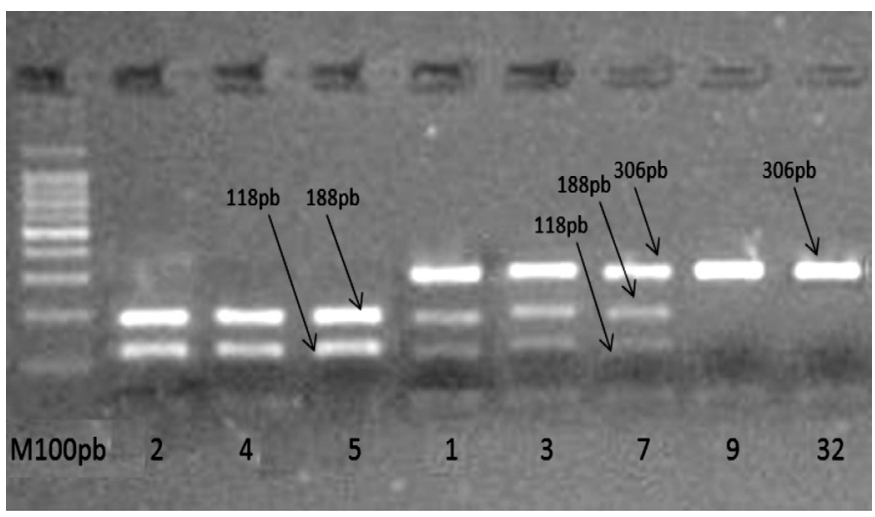

FIGURE 1. Digestion with the restriction enzyme AciI. The wild-type G/G genotype presents two fragments of 118 and 188 bp (patients 2, 4, and 5). The heterozygous $\mathrm{C} / \mathrm{G}$ genotype presents three bands of 306, 188 and $118 \mathrm{bp}$ (patients 1,3 , and 7 ). The homozygous mutant $\mathrm{C} / \mathrm{C}$ genotype destroys the restriction site and digestion produces a fragment of $306 \mathrm{bp}$ (patients 9 and 32).

\section{Statistical analysis}

The results were analyzed using the Statistical Package for the Social Sciences (SPSS, v 16.0). The Student t-test and $\chi^{2}$ test were used for comparison and odds ratios (OR) and their respective $95 \%$ confidence intervals $(\mathrm{CI})$ were calculated. Kaplan-Meier analysis and log-rank test were used to assess the stage genotype and survival. $P$ value $<0.05$ was considered to be statistically significant.

\section{RESULTS}

$\mathrm{G} / \mathrm{G}, \mathrm{G} / \mathrm{C}$ and $\mathrm{C} / \mathrm{C}$ genotypes frequencies was $42.7 \%, 50 \%$ and $7.3 \%$, respectively, in the control group and in the case group, the frequency of the genes was $59.0 \%, 34.0 \%$ and $7.0 \%$. The genotypic distribution is in Hardy-Weinberg equilibrium in control group $(P>0.05)$. The frequency of the genotypes and alleles differed between the groups $\left(c^{2}=6.786, P=0.033\right.$ and $\chi^{2}=6.697, P=0.010$, respectively). No association between GC and gender, age, alcohol consumption and smoking were observed in both groups (Table 1). 
TABLE 1. Characteristics of the study population

\begin{tabular}{|c|c|c|c|c|c|c|}
\hline Variable & Cases $\mathrm{n}=100$ & Controls $n=150$ & $P$ & $\mathrm{OR} *(95 \% \mathrm{CI})$ & $P$ & $\mathrm{OR} * *(95 \% \mathrm{CI})$ \\
\hline Gender & $\mathrm{n}(\%)$ & $\mathrm{n}(\%)$ & & & & \\
\hline Male & $54(54.0)$ & $78(52.0)$ & 0.756 & - & & - \\
\hline Female & $46(46.0)$ & $72(48.0)$ & & - & & - \\
\hline \multicolumn{7}{|l|}{ Age } \\
\hline Male & $61.5 \pm 12.4$ & $62.9 \pm 14.6$ & $0.265 \#$ & - & & - \\
\hline Female & $60.6 \pm 11.7$ & $60.4 \pm 15.8$ & $0.486 \#$ & - & & - \\
\hline Total & $61.1 \pm 12.0$ & $61.7 \pm 15.2$ & $0.731 \#$ & - & & - \\
\hline \multicolumn{7}{|l|}{ Smoker } \\
\hline Never & $40(40.0)$ & $60(40.0)$ & & 1.00 Reference & & 1.00 Reference \\
\hline Current + Ex-Smokers & $60(60.0)$ & $90(60.0)$ & 0.937 & $0.98(0.58-1.65)$ & 1.000 & $1.00(0.60-1.68)$ \\
\hline \multicolumn{7}{|l|}{ Alcohol drinker } \\
\hline No & $65(65.0)$ & $102(68.0)$ & & 1.00 Reference & & 1.00 Reference \\
\hline Yes & $35(35.0)$ & $48(32.0)$ & 0.716 & $1.11(0.64-1.90)$ & 0.622 & $1.14(0.67-1.95)$ \\
\hline \multicolumn{7}{|l|}{ Genotypes } \\
\hline $\mathrm{C} / \mathrm{C}$ & $7(7.0)$ & $11(7.3)$ & $0.099^{+}$ & 1.00 Reference & $0.033^{+}$ & 1.00 Reference \\
\hline $\mathrm{G} / \mathrm{C}$ & $34(34.0)$ & $75(50.0)$ & 0.559 & $0.73(0.26-2.07)$ & 0.519 & $0.71(0.25-2.00)$ \\
\hline $\mathrm{G} / \mathrm{G}$ & $59(59.0)$ & $64(42.7)$ & 0.444 & $1.49(0.54-4.10)$ & 0.473 & $1.45(0.53-3.98)$ \\
\hline C Allele & $30(20.6)$ & $97(23.3)$ & & 1.00 Reference & & 1.00 Reference \\
\hline G Allele & $116(79.4)$ & $203(67.7)$ & 0.009 & $1.87(1.17-3.00)$ & 0.010 & $1.85(1.16-2.95)$ \\
\hline $\mathrm{G} / \mathrm{C}+\mathrm{C} / \mathrm{C}$ & $41(41.0)$ & $86(57.3)$ & & 1.00 Reference & & 1.00 Reference \\
\hline $\mathrm{G} / \mathrm{G}$ & $59(59.0)$ & $64(42.7)$ & 0.012 & $1.93(1.15-3.23)$ & 0.011 & $1.93(1.16-3.23)$ \\
\hline $\mathrm{C} / \mathrm{G}+\mathrm{G} / \mathrm{G}$ & $93(93.0)$ & $139(92.7)$ & & 1.00 Reference & & 1.00 Reference \\
\hline $\mathrm{C} / \mathrm{C}$ & $7(7.0)$ & $11(7.7)$ & 0.870 & $0.92(0.34-2.47)$ & 0.920 & $0.95(0.36-2.54)$ \\
\hline No C Carriers & $59(59.0)$ & $64(42.7)$ & & 1.00 Reference & & 1.00 Reference \\
\hline C Carriers & $41(41.0)$ & $86(57.3)$ & 0.012 & $0.52(0.31-0.87)$ & 0.012 & $0.52(0.31-0.86)$ \\
\hline No G Carriers & $7(7.0)$ & $11(7.3)$ & & 1.00 Reference & & 1.00 Reference \\
\hline G Carriers & $93(93.0)$ & $139(92.7)$ & 0.870 & $1.09(0.40-2.92)$ & 0.920 & $1.05(0.39-2.81)$ \\
\hline
\end{tabular}

Values are means \pm standard deviation for continuous variables and $\mathrm{n}(\%)$ for categorical variables. $P$ for trend Pearson Chi-Square $\left(c^{2}\right)$ test;

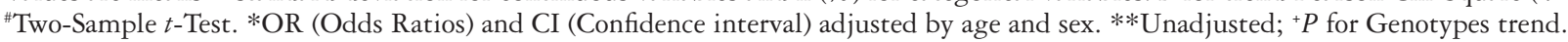

Genotype and allele frequencies of the COX-2 gene polymorphism in healthy controls and GC patients are shown in Table I. The risk of developing GC was higher among subjects with $\mathrm{G} / \mathrm{G}$ genotype compared to the others with $\mathrm{C} / \mathrm{G}$ or $\mathrm{C} / \mathrm{C}(\mathrm{OR}=1.93 ; P=0.012)$. The $\mathrm{G}$ allele also showed an elevated risk in $\mathrm{GC}$ patients $(\mathrm{OR}=1.87$;
$P=0.009)$ The number of GC patients were significantly higher in the non-C carriers $(\mathrm{C} / \mathrm{G}+\mathrm{GG})$ than in the $\mathrm{C}$ carriers $(\mathrm{C} / \mathrm{C})$ $(P=0.012)($ Table 1$)$.

A higher risk of GC was associated, by multivariate logistic regression analysis, with COX-2 -765 G/G genotype $(P=0.048$; OR: $1.98,95 \% \mathrm{CI}=1.01-3.90)($ Table 2$)$. 
TABLE 2. Multivariate logistic regression analysis stratified by the selected variables

\begin{tabular}{|c|c|c|c|c|}
\hline Variable & Cases $\mathrm{n}=100(\%)$ & Controls $\mathrm{n}=150(\%)$ & $P$ & $\mathrm{OR}^{*}(95 \% \mathrm{CI})$ \\
\hline \multicolumn{5}{|l|}{ Smoker } \\
\hline Never & $40(40.0)$ & $90(60.0)$ & & 1.00 Reference \\
\hline Smokers** & $60(60.0)$ & $60(40.0)$ & 0.949 & $0.98(0.49-1.96)$ \\
\hline \multicolumn{5}{|l|}{ Alcohol } \\
\hline No & $65(65.0)$ & $102(68.0)$ & & 1.00 Reference \\
\hline Yes & $35(35.0)$ & $48(32.0)$ & 0.249 & $1.55(0.74-3.28)$ \\
\hline \multicolumn{5}{|l|}{ Genotypes } \\
\hline $\mathrm{G} / \mathrm{C}+\mathrm{C} / \mathrm{C}$ & $41(41.0)$ & $86(57.3)$ & & 1.00 Reference \\
\hline $\mathrm{G} / \mathrm{G}$ & $59(59.0)$ & $64(42.7)$ & 0.048 & $1.98(1.01-3.90)$ \\
\hline
\end{tabular}

$P$ for trend; *OR (Odds Ratios) and CI (Confidence interval) adjusted by age and sex; ${ }^{*}$ Current Smokers + Ex-Smokers

Patients with advanced stomach cancer (stage IV) had poor survival $(P=0.003)$, but no difference on survival was observed among the genotypes in patients with $\mathrm{GC}(P>0.05)$.

\section{DISCUSSION}

Since the identification of the COX-2 -765G $>$ C polymorphism $^{(18)}$, studies have shown a correlation between this polymorphism and different types of cancer ${ }^{(3,21,25,30)}$. In this study we observed the frequency of the COX-2 -765 G/G, GC and CC genotypes were $59 \%, 34 \%$ and $7 \%$ in GC patients were similar to those previously reported by Pereira et al. ${ }^{(19)}$ for a Portuguese population ( $49 \%, 44 \%$ and $7 \%$, respectively). We found that the $\mathrm{C}$ allele occurs at a frequency of $20.6 \%$ in the GC patients. A high percentage of $\mathrm{C}$ allele had been observed among Portuguese ${ }^{(19)}$, Brazilian $^{(21)}$, and Dutch patients ${ }^{(25)}$ (22\%, 32\% and $41 \%$, respectively). Studies on European and American populations have reported a higher prevalence of $\mathrm{C}$ allele than studies involving Asian ${ }^{(2,4,10)}$.

In the control group, the frequency of the heterozygous $\mathrm{G} / \mathrm{C}$ genotype $(50 \%)$ was higher than that reported in other studies $^{(5,11,19,20)}$. The frequency of the homozygous mutant genotype was similar to the values reported by others authors ${ }^{(5,10,21)}$. The large number of individuals carrying the heterozygous genotype is probably due to the high rate of miscegenation in the Brazilian population, with major contributions from European and African populations ${ }^{(21)}$. Controversy exists in the literature regarding the association between the $-765 \mathrm{G}>\mathrm{C}$ polymorphism and GC. A Casecontrol Study using a Chinese Population was observed an increased risk of GC of 2.66-fold increase among carriers of this polymorphism ${ }^{(31)}$. Saxena et al. ${ }^{(22)}$, reported that the presence of the $\mathrm{C}$ allele was associated with a 8.2-fold (CI: 4.08-16.47) increased odds for GC. Pereira et al. ${ }^{(19)}$, observed a higher chance of progression to gastric adenocarcinoma among patients with atrophy or intestinal metaplasia carrying $\mathrm{C}$ allele. Other studies found no association between carrying $\mathrm{C}$ allele and $\mathrm{GC}$ patients ${ }^{(12,15)}$ or breast cancer patients ${ }^{(21)}$ as compared with control group.
In contrast, in the present study G/G genotype was found to be associated with a 1.93 fold higher risk of gastric cancer (95\% CI $=1.15-3.23)$. The presence of the $\mathrm{G}$ allele was associated with a considerably increased risk of cancer by 1.87 $(95 \% \mathrm{CI}=1.17-3.00)$. Similar results were reported by Sitarz et al. ${ }^{(25)}$, which showed an increased risk in patients with the G/G genotype (OR: $2.21,95 \% \mathrm{CI}=1.19$ to 4.08 ) for $\mathrm{GC}$ in the Dutch population. Hoff et al. ${ }^{(11)}$, also observed that the G/G genotype was associated with an increased risk of colorectal cancer (OR: 1.45, 95\% CI $=1.03-2.04)$.

We did not find any association between $-765 \mathrm{G}>\mathrm{C} \mathrm{COX}-2$ genetic polymorphism and lifestyle factors as smoking behavior and alcohol consumption in patients with GC. A similar results had been discussed by Xing et al. ${ }^{(29)}$ which also did not found association among alcohol drinkers and the -765 $\mathrm{G}>\mathrm{C}$ polymorphism.

The Kaplan-Meier survival curves for patients with advanced GC (stage IV) by staging system showed poor survival $(P=0.003)$ as also reported in the literature. No association was observed between genotype and survival. There are no studies in the literature investigating the association between the $-765 \mathrm{G}>\mathrm{C}$ polymorphism genotypes and survival in $\mathrm{GC}$ patients.

This study has some limitations such as the small number of patients with GC. Furthermore, ethnic differences influence genetical aspects.

In summary, this study showed a significant difference in distribution of $-765 \mathrm{G}>\mathrm{C}$ polymorphism in patients with $\mathrm{GC}$. The $-765 \mathrm{GG}$ genotype is associated with an increased risk of GC. Differences in genotype and allele frequencies between both groups suggest that COX-2 polymorphism can have a significantly different modulator of the disease in different ethnic populations.

\section{ACKNOWLEDGMENTS}

This work was generously funded by The São Paulo Research Foundation (FAPESP). 
Campanholo VMLP, Felipe AV, Lima JM, Pimenta CAM, Ventura RM, Forones NM. O polimorfismo -765 G>C do gene COX-2 e o risco de câncer gástrico na população Brasileira. Arq Gastroenterol. 2014,51(2):79-83.

RESUMO - Contexto - As alterações genômicas tem um papel importante na carcinogênese do câncer gástrico. As cicloxigenases (COX) são enzimas importantes na integridade da mucosa a nos processos patológicos, principalmente na inflamação e no câncer. $\mathrm{O}$ polimorfismo $-765 \mathrm{G}>\mathrm{C}$ COX-2 pode se relacionar ao risco de câncer gástrico. Objetivo - Avaliar o polimorfismo de COX-2 como um preditivo de risco de câncer gástrico. Métodos - Cem pacientes com câncer gástrico e 150 controles foram estudados provenientes de um centro no Brasil. Foram coletados dados referentes ao consumo de álcool e fumo, considerados fatores de risco. O DNA foi extraído de sangue periférico e os genótipos foram analisados por PCR- RFLP. Resultados - As frequências dos genótipos G/G, G/C e C/C foram 42,7\%, 50\% e 7,3\%, respectivamente nos controles e 59,0\%,34,0\% e 7,0\% no câncer gástrico. A frequência dos genótipos diferiu entre os grupos $(P=0,033)$. O genótipo -765G/G COX-2 esteve associado a um maior risco de câncer gástrico $(P=0,048$; OR:1,98, 95\% CI = 1,01-3,90). O consumo de álcool e o fumo em pacientes com o genótipo -765G/G COX-2 também aumentou o risco de câncer gástrico. Conclusão - O genótipo $-765 \mathrm{G} / \mathrm{G}$ e o alelo $-765 \mathrm{G}$ foi associado a maior risco de câncer gástrico. O fumo e o etilismo aumentaram o risco de câncer gástrico em indivíduos com o genótipo -765G/G comparados com o grupo controle.

DESCRITORES - Polimorfismo de nucleotídeo único. Câncer gástrico. Ciclo-oxigenase 2.

\section{REFERENCES}

1. Bakhle YS. COX-2 and cancer: a new approach to an old problem. Br J Pharmacol 2001;134:1137-50.

2. Brosens LA, Iacobuzio-Donahue CA, Keller JJ, Hustinx SR, Carvalho R, Morsink $\mathrm{FH}$, et al. Increased cyclooxygenase-2 expression in duodenal compared with colonic tissues in familial adenomatous polyposis and relationship to the -765G >C COX-2 polymorphism. Clin Cancer Res. 2005;11: 4090-6.

3. Cheng I, Liu X, Plummer SJ, Krumroy LM, Casey G, Witte JS. COX2 genetic variation, NSAIDs, and advanced prostate cancer risk. Br J Cancer. 2007;97:557-61.

4. Cipollone F, Toniato E, Martinotti S, Fazia M, Iezzi A, Cuccurullo C, et al. A polymorphism in the cyclooxygenase 2 gene as an inherited protective factor against myocardial infarction and stroke. JAMA. 2004;291:2221-8.

5. Cox DG, Pontes C, Guino E, Navarro M, Osorio A, Canzian F, Moreno V Polymorphisms in prostaglandin synthase $2 /$ cyclooxygenase 2 (PTGS2/COX2) and risk of colorectal cancer. British Journal of Cancer. 2004;91:339-43.

6. Dixon DA. Regulation of COX-2 expression in human cancers. Prog Exp Tumor Res. 2003;37:52-71.

7. Dubois RN, Abramson SB, Crofford L, Gupta RA, Simon LS, Van De Putte LB, Lipsky PE. Cyclooxygenase in biology and disease. FASEB J. 1998;12:1063-73.

8. Forones NM, Kawamura KY, Segreto HR, Artigiani Neto R, Focchi GR, Oshima CT. Expression of COX-2 in stomach carcinogenesis. J Gastrointest Cancer. 2008;39:4-10.

9. Gallo O, Franchi A, Magnelli L, Sardi I, Vannacci A, Boddi V, et al. Cyclooxygenase-2 pathway correlates with VEGF expression in head and neck cancer: implications for tumor angiogenesis and metastasis. Neoplasia. 2001;3:53-61.

10. Hamajima N, Takezaki T, Matsuo K, Saito T, Inoue M, Hirai T,et al. Genotype Frequencies of Cyclooxygenease 2 (COX2) Rare Polymorphisms for Japanese with and without Colorectal Cancer. Asian Pac J Cancer Prev. 2001;2:57-62.

11. Hoff JH, te Morsche RHM, Roelofs HMJ, van der Logt EMJ, Nagengast FM, Peters WHM. COX-2 polymorphisms $-765 \mathrm{G} \rightarrow \mathrm{C}$ and $-1195 \mathrm{~A} \rightarrow \mathrm{G}$ and colorectal cancer risk. World J Gastroenterol. 2009;15:4561-5.

12. Hou L, Grillo P, Zhu Z, Lissowska J, Yeager M, Zatonski W,. COX1 and COX2 Polymorphisms and Gastric Cancer Risk in a Polish Population. Anticancer Research. 2007;27:4243-8.

13. INCA. Instituto Nacional do Câncer: banco de dados. [update 2011 July; cited 2013 Aug]. Available from: http://www.inca.gov.br/estimativa/2010.

14. Jemal A, Siegel R, Ward E, Hao Y, Xu J, Murray T, Thun MJ. Cancer statistics. Cancer J Clin. 2008;58:71-96.

15. Liu F, Pan K, Zhang X, Zhang Y, Zhang L, Ma J, et al. Genetic Variants in Cyclooxygenase-2: Expression and Risk of Gastric Cancer and Its Precursors in a Chinese Population. Gastroenterology. 2006;130:1975-84.

16. Murata H, Kawano S, Tsuji S, Tsuji M, Sawaoka H, Kimura Y, et al. Cyclooxygenase-2 overexpression enhances lymphatic invasion and metastasis in human gastric carcinoma. Am J Gastroenterol. 1999;94:451-5.
17. Ohno R, Yoshinaga K, Fujita T, Hasegawa K, Iseki H, Tsunozaki H, et al. Depth of invasion parallels increased cyclooxygenase-2 levels in patients with gastric carcinoma. Cancer. 2001;91:1876-81.

18. Papafili A, Hill MR, Brull DJ, McAnulty RJ, Marshall RP, Humphries SE, Laurent GJ. Common promoter variant in cyclooxygenase-2 represses gene expression: evidence of role in acute-phase infl ammatory response. Arterioscler Thromb Vasc Biol. 2002;22:1631-6.

19. Pereira C, Sousa H, Ferreira P, Fragoso M, Moreira-Dias L, Lopes C, et al $-765 \mathrm{G}>\mathrm{C}$ COX-2 polymorphism may be a susceptibility marker for gastric adenocarcinoma in patients with atrophy or intestinal metaplasia. World J Gastroenterol. 2006; $12: 5473-8$.

20. Pinto S, Gallo O, Dilaghi M, Gallina E, Giannini A, Coppo M, et al. Prostaglandins in squamous cell carcinoma of the larynx: tumor and peritumor synthesis. Prostaglandins Leukot Essent Fatty Acids. 1990;39:53-7.

21. Piranda DN, Festa-Vasconcellos JS, Amaral LM, Bergmann A, Vianna-Jorge R. Polymorphisms in regulatory regions of Cyclooxygenase-2 gene and breast cancer risk in Brazilians: a case-control study. BMC Cancer. 2010;10:613.

22. Saxena A, Prasad KN, Ghoshal UC, Bhagat MR, Krishnani N, Husain N. Polymorphism of $-765 \mathrm{G}>\mathrm{C} \mathrm{COX}-2$ is a risk factor for gastric adenocarcinoma and peptic ulcer disease in addition to $\mathrm{H}$ pylori infection: A study from northern India. World J Gastroenterol. 2008;14:1498-503.

23. Sawaoka H, Kawano S, Tsuji S, Tsujii M, Gunawan ES, Takei Y, et al. Cyclooxygenase-2 inhibitors suppress the growth of gastric cancer xenografts via induction of apoptosis in nude mice. Am J Physiol. 1998;274:G1061-7.

24. Scioscia KA, Snyderman CH, Rueger R, Reddy J, D'Amico F, Comsa S, Collins B. Role of arachidonic acid metabolites in tumor growth inhibition by nonsteroidal antiinflammatory drugs. Am J Otolaryngol. 1997;18:1-8.

25. Sitarz R, Leguit RJ, de Leng WW, Polak M, Morsink FM, Bakker O, et al. The COX-2 promoter polymorphism - $765 \mathrm{G} / \mathrm{C}$ is associated with early-onset, conventional and stump gastric cancers. Mod Pathol. 2008;21:685-90.

26. Stoll BA. Indomethacin in breast cancer. Lancet. 1973;2:384.

27. Tsujii M, Kawano S, DuBois RN. Cyclooxygenase-2 expression in human colon cancer cells increases metastatic potential. Proc Natl Acad Sci USA. 1997;94 3336-40.

28. Ulrich CM, Bigler J, Potter JD. Non-steroidal anti-inflammatory drugs for cancer prevention: promise, perils and pharmacogenetics. Nat Rev Cancer. 2006;6:130-40

29. Xing LL, Wang ZN, Jiang L, Zhang Y, Xu YY, Li J, et al. Cyclooxygenase 2 polymorphism and colorectal cancer: $-765 \mathrm{G}>\mathrm{C}$ variant modifies risk associated with smoking and body mass index. World J Gastroenterol. 2008;14:1785-9.

30. Yang H, Gu J, Lin X, Grossman HB, Ye Y, Dinney CP, Wu X. Profiling of genetic variations in inflammation pathway genes in relation to bladder cancer predisposition. Clin. Cancer Res. 2008;14:2236-44.

31. Zhang JT, Wang MW, Zhu ZL, Huo XH, Chu JK, Cui DS, et al. Increased expression of cyclooxygenase-2 in fi rstdegree relatives of gastric cancer patients World J Gastroenterol. 2005;11:4918-22. 